'On the origins of abstraction: Seurat and the screening of history'

Sometime around 1883 Seurat painted the image of a ruined building on the surface of a small wooden panel [fig. 1]. The rectilinear shell of the four-storey structure is framed to the left by a sunlit tree and to the right by a distant edifice and a mass of darker foliage. In front of the building we see a large pond, though the visual clues are abbreviated: it takes a moment to recognize that the assorted strokes of paint represent the horizontal surface of a body of water, and the pond's circular form is barely telegraphed by the brief indication of its curved front edge in the painting's lower left corner. Above the pond is a light brown strip whose spatial orientation is equally difficult to decipher: is it a fence, a possibility suggested by the almost imperceptible vertical striations that mark the paint surface; or is it a ground plane sloping up towards the dark band that hides the base of the building? Over to the left are two summarily indicated elements that are even harder to read: a pallid white form and a light green rectangle at the painting's edge.

Though the image measures less than a foot across, the difficulty of reading its representational clues goes beyond that necessitated either by its size or by its schematic execution. Painting's ability to convey information about the world, about the nature of particular objects and the spatial relationships between them, has been partly suppressed in favour of a flattening out of the pictorial field. Foreground and middleground are telescoped into a shallow space by the insistent frontality of the ruins and by the alignment of depicted objects with the shape of the panel itself (note how the uppermost window frame neatly coincides with the panel's upper edge and how the far side of the circular pond has been straightened to line up both with the panel's edge and with the horizontal band of dark paint above). The image is further flattened by the array of criss-cross strokes and dabs of pigment from which the painting is constituted and which elicit the viewer's attention as much as the representational content of the picture. ${ }^{1}$ That we are looking at a flat surface is underlined by the visibility of the unprimed wooden support: the brown hue of the distant building is that of the panel, clearly observable between sparse touches of violet pigment. $^{2}$

These qualities might lead us to conclude that the image concerns itself less with the scene it depicts than with formal questions such as the rhyming of shapes 
across the surface and the foregrounding of an emphatic facture, a conclusion that would echo the view of the great defender of modernist abstraction, Clement Greenberg. 'Seurat's interest,' he wrote in 1943, 'was to secure for painting most economically and expeditiously the maximum of the effects proper to it as a twodimensional art imprisoned on a flat surface, ${ }^{3}$ a claim that located Seurat within the account of modernism that the critic had first articulated four years earlier in 'AvantGarde and Kitsch'. While the early avant-garde (Greenberg's prime example being Courbet, about whom we will have more to say below) was characterised by the critical distance from bourgeois culture that emerged with 'the first bold development of scientific revolutionary thought' (i.e. Marxism), by the early 1880s advanced painting had, Greenberg believed, abandoned any such explicit engagement with politics. ${ }^{4}$ 'The revolution was left inside society', and avant-garde artists busied themselves instead with an investigation of 'the disciplines and processes' of art itself. $^{5}$

Greenberg's diagnosis, I will be arguing, was both right and wrong: right in identifying a general downplaying of representation in favour of an increased attention to formal properties in advanced painting such as Seurat's (on this point there is general agreement in the literature, which routinely notes the suspension of Seurat's early work between image and surface ${ }^{6}$ ); wrong in interpreting this as a move away from politics - as a withdrawal, as he famously put it, from the 'welter of ideological struggle."7 What Greenberg did not grasp, and what as yet remains underexplored in the literature, is how the balance between representation and its suppression in such images was tied in concrete ways to the politics of the French Third Republic. That we sense ourselves losing sight of the ruins in Seurat's small panel is not, I will suggest, the sign of a burgeoning interest in merely formal qualities; it is, rather, the symptom of a crisis in historical memory that became one of the structuring principles of French politics in the early 1880s. ${ }^{8}$

One of the central claims in what follows will be that Seurat's work of this period can best be understood as a working-through both of the trauma of the Paris Commune (a trauma that the Third Republic was by 1880 actively seeking to forget) and of a series of partly-repressed memories of French naturalist painting. ${ }^{9}$ These twinned histories, I will argue, are screened in Seurat's early paintings and drawings in both senses of the word: put on display, but at the same time hidden from view. It 
is this doubled screening, this simultaneous play of making visible and withholding from sight, that ties his work to the politics of its moment.

Examining this question will allow us to revise our understanding of the political connotations of Seurat's early work (and, by implication, of his later canvases, though I will not address these here ${ }^{10}$ ). Equally importantly, it will raise wider questions about the origins of abstraction. An attention to formal qualities would be central to the emergence of abstract art in the second decade of the twentieth century, and Seurat's work both predicts this development and makes clear that, at least in its early moments, this development was inseparable from historical and ideological concerns. ${ }^{11}$ Abstraction, Seurat's work suggests, was haunted by politics from the start. ${ }^{12}$

\section{The Tuileries Ruins}

That politics might be part of what Seurat's early work grappled with is already suggested by the picture with which we began. For if this is a painting that concerns itself in part with pictorial structure, it is clear that another kind of structure - the ruined edifice whose faltering image sits at the centre of the small panel - is equally and unavoidably what we are asked to attend to. We are looking at the remains of the Tuileries Palace, torched at the tail end of the Commune and in the early 1880s the most visible reminder of the violence that had shaken the capital in May 1871. (The mansard roofs beyond belong to the Louvre's Denon wing, undamaged by the conflagration that consumed the Tuileries.)

The palace was set alight on the evening of 23 May 1871 by Communards retreating from the French army as it retook the capital in the name of the fledgling Third Republic. Thereafter the future of the burnt-out ruins had been bitterly contested. Monarchists urged the government to restore the building in preparation for a future king's return; those on the left recommended on the contrary that the ruins be removed in order to incorporate the Tuileries gardens and the Louvre courtyard into a unified public space. ${ }^{13}$ The success of republican candidates in the elections of 1877 led to increased support for demolition, and in 1879 the Chamber of Deputies voted to raze the edifice. ${ }^{14}$ The Senate, more politically conservative, refused at first to pass the law, but in 1881 the Chamber renewed the push for demolition after moving still further to the left. Some proposed that a replica of the central section of 
the building be constructed (the idea was not so far-fetched: the Hôtel de Ville had been rebuilt from the ground up after being torched during the Commune); others suggested that a new design be developed to house not a king but a museum of modern art, and Charles Garnier was commissioned to draw up the plans. These projects, however, came to naught, and after another year or so of political wrangling Antonin Proust, ministre des Arts and subject of a famous portrait by his friend Édouard Manet, succeeded in getting the law authorizing demolition through the Senate. Work finally began in 1883. The first stones were carried off in February, and within seven months all trace of the building had been removed. Most of the rubble was sold to a private buyer, who in turn sold fragments of the façade as souvenirs: architectural relics in every sense. ${ }^{15}$

There is good reason to suppose that Seurat painted Ruins of the Tuileries during the course of the building's demolition, as is apparent if we compare his image with Siebe Johannes Ten Cate's The Tuileries Palace after the fire of 1871, seen from the Great Pond in the garden [fig. 2]. Ten Cate's image resolves some of the uncertainties in the Seurat: the latter's ambiguously oriented pale brown strip is more clearly indicated to be a sandy forecourt that ascends gradually from the pond to the ruins; the dark band above is shown to be a palisade fencing in the ruins; and it becomes evident that the pallid object in the Seurat must be one of the damaged sculptures that stood for a decade as testimony to the destructive events of 1871. (The Ten Cate does not help to identify Seurat's green rectangle, but photographs of the Tuileries gardens indicate that it is a wooden box housing the pond's filtration system [fig. 3].) More importantly, Ten Cate's depiction indicates that in 1880 - the year that he painted his image - the remains of the palace were far less skeletal than in Seurat's picture. The front and rear walls were by and large intact and the building extended across much of the space between the Louvre's two wings, its width only slightly curtailed by an initial phase of demolition in 1878 that cleared space for the reconstruction of the pavillons de Flore and de Marsan (the points at which the Louvre connected with the Tuileries, and the only parts of the former to be damaged in 1871). In Seurat's painting both the depth of the ruins and their lateral extension are in contrast drastically reduced. The foliage to the left is thin enough to allow us to see that the building does not continue behind it, which is to say that the section depicted by Seurat stands in isolation, barely three bays wide. It would seem, then, 
that Seurat painted the ruins as their demolition neared completion, depicting the last remains of the palace before it finally disappeared from view.

Seurat thus chose to represent a landmark with unavoidably political associations (as we shall see, even images like Ten Cate's took part in the debate about the palace's future), and in all likelihood did so at the very moment of its muchcontested demolition. Yet despite the loaded subject matter, this cannot be described in any straightforward way as a political painting. ${ }^{16}$ Seurat may have been called a Communard by his fellow students during a brief stint at the École des Beaux-Arts in the later 1870s, but his depiction of this most stark reminder of the Commune’s violent ending reveals no such partisan affiliation. ${ }^{17}$ Instead, its emphasis on pictorial structure renders the ideological associations of the site somewhat mute. ${ }^{18}$ Not, however, completely mute: what we see here is not the withdrawal described by Greenberg. Like the ruined palace, suspended for a decade between an uncertain future and the ghosts of the past, Seurat's painting is Janus-faced. Its foregrounding of pictorial structure may predict the modernist dispensation to come (though to put it like this is to risk falling into the kind of teleological thinking that marred Greenberg's analysis; better to say that Seurat develops certain pictorial devices flattened space and an emphatic facture, most notably - that would be put to other kinds of work by later artists ${ }^{19}$ ). But its invocation of the lingering memory of the Commune means that it looks equally toward the past, toward the troubled political history of France. The welter of ideological struggle, that is to say, remains fully in play, only partially occluded by - and, I will be arguing, in fact embodied in - the painting's formal devices.

\section{The Spectre of the Past}

We will analyze more precisely the nature of this partial occlusion - and specifically how formal devices that would later be characterized as proto-abstract function in Seurat's work as a screen haunted by history - in the second half of this paper. ${ }^{20}$ Not only Seurat's subject matter but also his technique, as we shall see, invoked a past (the naturalist tradition) whose ideological associations were seen, like the ruins of the Tuileries, as themselves being in suspension in the early 1880s. Before addressing this question, however, we must first locate Seurat's work within the context of the crisis in historical memory that marked the Third Republic. 
That crisis found its point of origin in the trauma of the Commune. Consider the most famous account of the events of March-May 1871, Karl Marx's The Civil War in France. ${ }^{21}$ Marx began the text in mid-April, a month or so after the Communards siezed control of Paris on the $18^{\text {th }}$ of March, and much of the text was written in the next few heady weeks when it seemed that the revolutionary utopia was at hand. Marx finished writing, however, at the end of May. He dated the text to the $30^{\text {th }}$ of that month, two days after the French army regained control of the capital after a week of the most shocking bloodshed (the death toll was contested, but most accounts hold that 30,000 Parisians died during the infamous semaine sanglante). Thus when Marx put his signature to the text, the Commune was already past, already dead. History had repeated itself, with the forces of order - as in 1848, as in 1830, as in all earlier revolutionary moments - regaining control. Marx's account is thus riven by temporal indeterminacy, looking optimistically to the future but already haunted by the spectre of the Commune's failure.

This division marks the text itself, which exhibits a pronounced uncertainty about the relationship between revolutionary future and reactionary past - an uncertainty that recalls the temporal ambivalence identified by Jacques Derrida in Marx's Eighteenth Brumaire, written nineteen years before The Civil War in France in response to Napoleon III’s 1851 coup d'état. There Marx had noted the difficulty, even when revolutions remade society (as in 1789), of escaping the past:

Men make their own history, but they do not make it just as they please; they do not make it under circumstances chosen by themselves, but under circumstances directly encountered, given and transmitted from the past. The tradition of all the dead generations weighs like a nightmare on the brain of the living. ${ }^{22}$

When writing The Civil War in France, I would suggest, Marx was similarly attuned to the difficulty of escaping the past, though this is not immediately apparent in the dominant rhetoric of his account, which mostly revolves around the characterization of the Commune as the living present and reserves for the forces of reaction the charge of being nothing more than the deathly vestiges of the past. 
Listen, for example, to his description of the government of the newlyfounded Third Republic, forced to flee Paris and now residing (all too tellingly) at the former residence of the French monarchs:

Opposed to this new world at Paris [i.e. to the Commune], behold the old world at Versailles - that assembly of the ghouls of all defunct regimes, Legitimists and Orleanists, eager to feed upon the carcass of the nation . . . and caricaturing 1789 by holding their ghastly meetings in the Jeu de Paume. There it was, this Assembly, the representative of everything dead in France, propped up into the semblance of life by nothing but the swords of the generals of Louis Bonaparte. ${ }^{23}$

Marx presents the political struggle as being clearly divided between past and present, death and life. At Versailles royalists of various stripes rub shoulders with the military servants of the Second Empire; together these groups comprise the very incarnation of reactionary politics, gathered at the spiritual home of the Ancien Régime to plot their return to power. In Paris, in contrast, are to be found the progressive forces that would sweep this old order - ghastly and ghostly - from the political stage.

Elsewhere in the text, however, Marx acknowledges that the Commune, much as 1789 had been, is itself haunted by the past. Sometimes, he suggests, seeing the Commune in this way is simply an error made by other commentators. He notes, for example, that because '[i]t is generally the fate of completely new historical creations to be mistaken for the counterpart of older and even defunct forms of social life, to which they may bear a certain likeness', the Commune was erroneously seen by some as a resurrection of the medieval communes. ${ }^{24}$ But he himself also describes 1871 in terms of the past, observing the residue of earlier historical formations within the Commune:

In every revolution there intrude, at the side of its true agents, men of a different stamp; some of them survivors of and devotees to past revolutions, without insight into the present movement but 
preserving popular influence by their known honesty and courage, or by the sheer force [the 'dead weight', as he had written earlier] of tradition; others mere bawlers, who by dint of repeating year after year the same set of stereotyped declamations against the Government of the day, have sneaked into the reputation of revolutionists of the first water. After the $18^{\text {th }}$ of March some such men did also turn up, and in some cases contrived to play preeminent parts. As far as their power went, they hampered the real action of the working class. ${ }^{25}$

The closing observation seeks to reinstate the desired boundary between the 'real' Commune - active and forward-looking - and the lifeless remnants of earlier political formations. But those remnants were, Marx acknowledged, at the heart of the action in 1871. The problem, then, was one of making distinctions: how to know which voices in the Commune were honest but outdated, which mere bawlers, and which the real thing?

The text is most troubled by the question of what the return of the past means when Marx describes revenants not as the deathly and counter-revolutionary residue of previous epochs - as he had in his evocation of the Versaillais - but as the animating force of the Commune itself:

'The men of order', the reactionists of Paris, trembled at the victory of the $18^{\text {th }}$ of March. To them it was the signal of popular retribution at last arriving. The ghosts of the victims assassinated at their hands from the days of June 1848 , down to the $22^{\text {nd }}$ of January 1871, arose before their faces. ${ }^{26}$

The presence of the past, described elsewhere in the text as the lingering husk of outmoded traditions soon to be swept away (Versaillais ghouls outstaying their welcome), is here offered up as the very essence of the revolutionary force that will displace the established order. The victims of regimes both royal and republican are invoked as the animating spirit of the Commune: dead, but representative of the vitality that will carry the revolution into the future. 
Marx, then, was ambivalent about what the return of the past might mean in 1871 and, consequently, about what the orientation of the present moment might be: forward-looking, or transfixed by deathly memories that tied it to the past. And in this he was not alone. Writers of a very different political stripe were equally preoccupied - and remained so for a decade and more - by the question of whether the return of the past in 1871 had been revolutionary or counter-revolutionary. Toward the end of the 1870s, Maxime du Camp, one of the most vicious of the Commune's many enemies, conjured the image of veterans of the Napoleonic campaigns returning to protect the Vendôme Column as it was about to be felled on 16 May 1871 (allegedly on the orders of Courbet). This was the past as counterrevolution returning to maintain order. ${ }^{27}$ It was also the past as living presence: Du Camp was describing aged veterans, not ghosts. For the equally conservative Ernest Daudet, recalling the Commune at the end of the century, the past that returned in 1871 had in contrast been thoroughly deathly, and on the side of the (for him, illegitimate) revolution: the Commune, he declared, had been a pale imitation of the 'pompous and puffed up rhetoric' of 1789 (Daudet here - wittingly or not - himself imitates Marx’s description of Napoleon III as the enervated echo of his uncle, Napoleon Bonaparte). ${ }^{28}$ Again, as with Marx, we hear the same uncertainty: did the past return as living force or as deathly repetition?

\section{Willed Amnesia}

That the Commune's relationship to its own past was difficult for commentators to pin down was a symptom, I would suggest, of the difficulty experienced by the Third Republic in making sense of its own relationship to the Commune. The Republic's first truly significant act (along with suing for peace with Prussia) was to unleash the brute power of the army on its own citizens. The longawaited Republic, dreamed of (by liberals, at least) throughout the Second Empire, was thus stained from the start. The re-emergence of democratic government at the national level was tied inextricably to the violent suppression of a democraticallyelected civic body (the Commune had held elections on the $26^{\text {th }}$ of March, just eight days after its inception). The resulting trauma was one that could not easily be accommodated into a palatable account of the Republic. ${ }^{29}$ 
One solution to this problem was to vilify the Commune in order to justify the violence with which it had been suppressed. The obsessive repetition throughout the 1870s of accounts that blackened the reputation of the Communards testifies to the important work done by such narratives (participants in the Commune were held to have been motivated by vindictive hatred and to have been for the most part drunk and degenerate). ${ }^{30}$ But this tactic failed to fully exculpate the bloody acts of the Republic; if anything, the repetition ended up keeping the semaine sanglante - and by implication the Republic's own violence - firmly in the public's mind.

For this reason an alternate solution gained traction towards the end of the decade: namely, the desire to forget the events of 1871. A willed amnesia effectively became official government policy in July 1880 when a general amnesty (amnesty and amnesia, of course, have the same root) was offered to the majority of former Communards. ${ }^{31}$ Léon Gambetta, the de facto leader of the Chamber of Deputies, pushed for the amnesty in the name of a united Republic: 'You must close the book of these last ten years, you must lay the tumulus stone of oblivion on all the crimes and all the vestiges of the Commune, and tell everyone that there is only one France and only one Republic. ${ }^{32}$ Extensive July $14^{\text {th }}$ celebrations were arranged to seal this forgetting of the past. And though not everyone was willing to play along - in mid1882 the radical Jules Vallès was still describing the Tuileries as the 'classic terrain of civil war' 33 - most were happy enough to forget. Thus Vallès' site of memory would itself soon disappear: the demolition of the Tuileries ruins was integral to the amnesiac drive.

Painters also played their part. In earlier years artists had for the most part simply refused to look at the ruins. Claude Monet is perhaps the most famous proponent of this approach, ably demonstrating in the mid-1870s how to compose a pleasing picture of the Tuileries gardens and the end of the Louvre's pavillon de Flore without showing the remains of the palace [fig. 4]. Here the refusal to look is so pronounced - the ruins are just a few feet off to the left - that this unwillingness becomes part of the work's meaning: this is art explicitly declaring that it wants nothing to do with the memory of the capital's violent past. The palace is pushed from view, just as the Communards were when in their thousands they were banished to the French penal colony in New Caledonia. ${ }^{34}$ 
Around the time of the amnesty this refusal took on new, more nuanced forms. Like the ex-Communards, visible once more on the streets of the capital but emptied (at least to some degree) of their political charge by having had their 'crimes' pardoned, the ruins reappear in painting stripped in large part of their association with the Commune. Thus Guiseppe de Nittis's Place du Carrousel: Ruins of the Tuileries in 1882 [fig. 5] forgets not the ruins per se - they are perfectly visible at the centre of his picture - but rather their historical resonance. Nestling unobtrusively amidst the modern-day leisure and work activities of a sunlit Paris, the ruins are made to look neutral, just an edifice amongst others, and passers-by go about their daily business unconcerned by the traumatic history of the space. While the manifest purpose of the painting was commemorative - to record the building before it disappeared - its latent purpose was precisely the opposite: not to remember, but rather to forget the political associations of the building. The smoke that rises at the left exorcises the memory of 1871 by recalling for a moment the flames by which the building was destroyed before neutralizing this association by making plain that fire has now been tamed, brought to heel in one of the workshops engaged in the orderly dismantling of the ruins.

The downplaying of the ruins' significance was, we might note, resisted by more conservative painters. Jean-Louis-Ernest Meissonnier's Ruins of the Tuileries [fig. 6], begun in 1871 but first exhibited, significantly enough, in September 1883 i.e. shortly after the demolition - insisted that the building's association with the destructiveness of the Commune remain visible. ${ }^{35}$ Looking through the ravaged palace we see atop the Arc du Carrousel the personification of Peace, a figure misidentified as Victory in Meissonnier's written account of the painting in order to give the sculpture's orientation away from both ruins and viewer a specific meaning: that victory had at the moment of the Commune deserted France. ${ }^{36}$ The painting also suggests, though, that all was not lost. Meissonnier included the two words that he claimed to have been able to read on the charred walls of the Hall of the Marshalls into whose roofless space we look: Marengo and Austerlitz, two of Napoleon's great victories. And he added to the fallen stone in the foreground the hopeful Latin inscription, ‘Gloria majorum per flammas usque superstes' ('The glory of our ancestors surviving always through the flames'). Meissonnier’s Bonapartiste leanings are clear (under the Second Empire he had painted innumerable images celebrating 
Napoleon and his military campaigns); equally clear is the blame he attaches to the Commune for laying waste to that legacy (though strictly speaking it was the Third Republic, and not the Commune, that had put an end to the régime of Napoleon's nephew). And these meanings were public: when Ruins of the Tuileries was reexhibited at Meissonnier's 1884 retrospective at the Galerie Georges Petit the catalog explained in detail the painting's intended significance. ${ }^{37}$

Meissonnier's insistence on remembering the destruction associated with the Commune was, however, unusual in the 1880s. De Nittis's image and the ideological stance associated with it were closer to the requirements of the amnesty, a necessary preparation for the subsequent demolition of the Tuileries. The significance of the ruins had to be actively forgotten (a contradiction in terms, of course) before they could finally be disposed of physically. It is not surprising, then, that De Nittis's painting was bought by the Ministère de l'Instruction Publique in June 1883 at the instigation of Proust. ${ }^{38}$ Nor that when the painting was exhibited later in the year at the Exposition Nationale the critics seemed - or perhaps sought to appear - blithely unaware of the traumatic history of the site it depicted. ${ }^{39}$ The administration's interests were served equally well by Ten Cate's view of the ruins, and by another by the same artist that, like de Nittis's, showed the remains of the palace from the Louvre side. Again, the painter's dispassionate gaze rendered the ruins inert.

\section{Seurat and the Dialectics of Memory}

It seems fair to say that Seurat's image stands in rather uncertain relation to such paintings and to the crisis in historical memory that marked the Third Republic in the early 1880s. Ruins of the Tuileries is, for one thing, a private work, never meant to be exhibited and thus not part of the public debate in which images such as De Nittis's and Ten Cate's intervened. Perhaps more importantly, whilst it seems to grapple with the memory of the Commune, its outlook is decidedly opaque. What exactly its attitude to history might be, how it remembers or forgets the trauma of the Commune, is difficult to pin down. ${ }^{40}$ As Marx understood, the return of the past is hard to read, its politics uncertain.

To some degree the image might be seen as participating in the amnesiac drive. Embedding the ruins in a densely-worked surface that mutes their ideological resonance, it repeats - though in radically different form - the act of forgetting 
performed by the likes of de Nittis. Despite their proximity and their dominant role within the image, the ruins hover indeterminately in the flattened space, unable to be brought fully into focus no matter how hard the viewer looks. A largely unmodulated mass (only the barest hints of shadow suggest the indentations and protrusions of sills and attached pilasters), the edifice does not fully hold the gaze. ${ }^{41}$ The eye is instead deflected to other points of interest: the purple of the mansard roofs beyond, the flicker of reflected light on the pond's surface, the illegible green form at lower left.

And yet, despite their inability to hold the viewer's attention, the ruins remain implacably centre stage. This is declaredly a picture of the ruins in a way that de Nittis's is not. And more to the point, it is a picture of the ruins at the moment of their demolition - at the moment, that is to say, when they were officially being 'forgotten.' The painting thus takes as its subject one of the central and certainly the most concrete signs in the early 1880s of the Third Republic's effort to lay Gambetta's tumulus stone of oblivion over the memory of the Commune.

In this light the painting's technique takes on added significance. The imprecision of the image may mute the ruins, may allow them (or at least their political resonance) to be forgotten to some degree. But they are not, in the end, forgotten. Rather it is as though we see them being forgotten. The ruins seem to fade from view before our eyes, the palace appearing as a spectral presence whose solidity evanesces as its form recedes into the criss-cross array of interwoven brushstrokes. Twinned as it is with the theme of demolition, the painting's paradoxical balance between making the palace's skeletal contours present and allowing them to disappear makes Ruins of the Tuileries in effect a picture of forgetting. The image, we might say, gestures dialectically towards the historical amnesia practised by the Third Republic: it forgets, but at the same time foregrounds the act of forgetting in its technique as well as in its subject matter. It thus necessarily keeps in mind that which was to be effaced, pointing to the impossibility of the willed amnesia practiced by de Nittis and Ten Cate.

I realize that putting it in these terms risks making the painting - and its meaning - come across as rather more defined than it is. To speak of dialectical gestures and of a foregrounding of forgetting is to pin down the significance of this small panel too neatly, to fix too precisely in place its ideological resonance. The image itself is less certain than this. It holds meaning in suspension, and its resistance 
to the possibility of a final reading makes it hard to find words that get hold of what we see here without overstating the case ('getting hold of' is what the panel refuses at every level). But if this is a picture that makes us prevaricate, that forces us to hedge our interpretive bets, it is thus one that holds history - the historical materials with which it deals - in suspension. This is the primary cause of our prevarication; it is also, of course, what allows the image to resonate with the Third Republic's willed amnesia.

Later we will have more to say about how Seurat's technique in and of itself simultaneously invokes and occludes the past (which is to say, about how the technique screens history in both senses). First, I want to consider another small panel painted at around the same time as Ruins of the Tuileries in which historical amnesia plays an equally central role. Here, as we shall see, it is the history of nineteenth-century French painting as well as the history of the Commune that is invoked.

The Stonebreakers, Le Raincy [fig. 7] depicts three figures, one male, two female, standing on a broad expanse of what we take to be the stones they must break. Behind them a small pile perhaps represents the fruit of their labour. To the left a horizontal white line suggests a barrier - perhaps at the edge of the road, if that is what they are working on - and beyond we see a dense screen of foliage marked here and there by quickly indicated trunks or branches. The even light by which the scene is illuminated - there are few clues, bar the hint of a shadow behind the woman to the right, as to the location of the sun - gives the picture a somewhat intangible quality, as though the workers are on view but not fully graspable as concrete bodies.

In this The Stonebreakers, Le Raincy, despite its very different subject, resembles Ruins of the Tuileries, and there are other similarities. The orientation of the ground upon which the figures stand is hard to decipher (horizontal or inclined?), and space is even more difficult to read at the lower corners of the image. Equally ambiguous is the angle at which the central figure holds her slender-handled hammer: is it slung back over her shoulder as she tenses in preparation to begin swinging it forward (i.e. is it angled away from us), or is it already in motion, hurrying down towards the stones at her feet (i.e. angled towards us)? Her male companion's hammer, roughly parallel to hers, suggests an interest in aligning objects on the surface, as does the emphatic horizontal of the barrier and the road's edge, and the 
surface itself is further emphasized by the image's construction from repeated dabs of paint deposited by a square-ended brush. The paint is more thickly applied than in Ruins of the Tuileries and the regularity of the blocky strokes is more marked, but the net result is roughly the same: the three figures, like the ruins, are encased in a unifying screen of pigment. Note the larger strokes that constitute both the central woman's body and the stones beyond her, locking figure and ground together.

Like Ruins of the Tuileries, then, this is an image that attends centrally to pictorial structure. But again, it seems fair to say that what is depicted is far from neutral: it will already have struck the reader that the theme echoes that of a wellknown prototype, Courbet's Stonebreakers of 1849 [fig. 8]. Seurat's painting is, of course, very different (not least because of its mixed-sex cast), but there are enough similarities to suggest that Courbet was the source, especially when we consider the extended series of stonebreaker images that Seurat created in the early 1880 s. We know of seven or perhaps eight oil sketches and four drawings in which Seurat arranged and re-arranged the components of Courbet's picture. ${ }^{42}$ The Stone Heap (Le Tas de pierres) [fig. 9] is the closest in overall arrangement, with Courbet's hatted older figure simply shunted across to the left and allowed to stand somewhat more erect, whilst the boy (perhaps still holding a basket or sack, though the imprecision of the image allows us only to sense that he attends to - and perhaps holds - something before him) is rotated around the central axis of the painting to reappear facing forward on the right. In another version [fig. 10] the figures are in roughly the same position within the composition, though the right-hand figure now faces away from the viewer and the left hand figure has lost his hammer (he appears to be wiping sweat from his brow). In both examples, as in The Stonebreakers, Le Raincy, the background foliage blocks out the sky, much as the dark hillside did in the Courbet (bar a small patch of blue in the upper right corner). Seurat also produced a number of single-figure variations in which we see repeatedly the bowed figure, hammer sometimes overhead, sometimes striking the ground, with the figure at times parallel to the surface, at others angled in. He may even have toyed with the idea of working up a large-scale composition on the theme: Stonebreaker and other figures, Le Raincy [fig. 11], by far the most fully elaborated of the drawn versions, feels very much like a preparatory study. ${ }^{43}$ 
That the connection to Courbet has rarely been made is probably due to the widespread assumption that neo-impressionism (and, by extension, Seurat's painting before neo-impressionism) was always forward-looking, tied to advanced artistic practices such as impressionism rather than earlier variants of naturalism. ${ }^{44}$ However, being forward-looking was no simple matter around 1880: Marx was not alone in understanding that as often as not it was entangled with the ghosts of the past. And it would not be altogether surprising if Seurat had Courbet in mind in the early 1880s. Having died in exile in 1877, the great Realist was briefly resurrected by the Gambetta-led administration (the same political bloc that granted the amnesty to exCommunards and that would push through the decision to demolish the Tuileries). Under Proust's direction the state very publicly acquired some of Courbet's most important paintings from his surviving sister, Juliette, who donated the Burial at Ornans to the Louvre on condition that the state purchase a number of works from the Courbet sale of 9 December 1881. At the same time, the Gambetta administration forced the École Nationale des Beaux-Arts, the stronghold of precisely those academic painters who had been most rigidly opposed to Courbet, to host an extensive retrospective exhibition of more than 140 of his paintings and drawings. ${ }^{45}$ Jules Castagnary, long one of the artist's most loyal supporters, was a key figure in the organization of the retrospective, which opened in April 1882 with the Stonebreakers as its centerpiece.

With Courbet's posthumous star riding high, it is easy to imagine an ambitious young artist taking him as a model. As Seurat worked on Stonebreaker and other figures, Le Raincy, he perhaps had in mind the kind of large-scale painting for municipal buildings that had been promoted by Castagnary since the mid-1870s in his role first as Secretary then as President of the Conseil de Paris. ${ }^{46}$ If so, the relocation of the stonebreaker to an anonymous and socially-fragmented suburb would have been particularly apt, echoing the favoured social terrain of the Naturalist novel beloved of Castagnary and his colleagues. Note the lack of interaction between the stonebreaker, the child-carrying postman or rag-picker (his shoulder bag has led him to be identified as both), and the woman beyond, and also the difficulty of grasping each individual's relation to their setting. ${ }^{47}$ But if Seurat was planning such a painting, he never produced it. For his first major canvas, begun a year or so later, he 
turned his attention not to labouring bodies but to the depiction of workers at rest in Bathers at Asnières.

Perhaps the shifting political ground put him off: Gambetta's hold over the Chamber soon waned and the administration's promotion of Courbet's realism ceded to support for the polished naturalism of painters such as the academically-trained Jules Bastien-Lepage (a government favourite since the mid-1870s). ${ }^{48}$ Or perhaps he realized that to engage publicly with Courbet's notorious masterpiece was too risky a venture. The Gambetta administration might have briefly resurrected the master of Ornans, but others still despised both his art and his politics, in part because his reputation had since 1871 been inextricably tied to his participation in the Commune (convicted of orchestrating the felling of the Vendôme Column and ordered to meet the impossibly high cost of its reconstruction, he was forced into exile in Switzerland ${ }^{49}$ ). Many thus wished actively to consign him to oblivion. For some this meant refusing to speak about his work at all $^{50}$; for others it meant rewriting his story, seeking to divorce his art from radical politics and from his oft-lamented involvement in the Commune so that it might be presented as simply and naïvely devoted to nature. ${ }^{51}$

Courbet was thus, like the Commune itself, the subject of a willed amnesia. And as with Ruins of the Tuileries, Seurat's series of stonebreakers seem to wrestle with this fact. This is evident first in the fact that Seurat did not exhibit the stonebreakers images, and presumably never intended to. He may have been contemplating a large-scale work, but the various studies seem equally geared to a private exploration of Courbet's legacy, the memory of which is thus, like the master of Ornans himself, positioned at the margins of the public sphere.

More importantly, Courbet's status as an artist half-remembered, halfrepressed, is figured in the appearance of the works themselves. Consider The Stonebreakers, Le Raincy. Despite certain similarities - the bare-torsoed man who echoes Courbet's young boy in his three-quarter turn into depth, for example, or the wall of green that hems in the figures in a repetition of the claustrophobic backdrop of Courbet's picture - the image feels far less engaged than its prototype. The exhaustingly repetitive nature of manual labour may be implied in the stilted pose of the woman on the right, but the constitution of the image from repeated taches makes it difficult to sense in any visceral way the effort of the depicted work; if anything, the 
visibility of the facture leaves us as aware of the painter's activity as we are of that of the stonebreakers. ${ }^{52}$ Much the same effect is produced by the way in which Courbet's precise delineation of torn and historically-specific clothing cedes to a vague indication of trousers, skirts, tops and hats that gives little away in terms of the class of the figures (maybe it is a peasant's blouse on the right, but Seurat doesn't allow the viewer to be sure). Bar a few vague clues - the man perhaps wears denim trousers practically all sense of the materials from which the clothes are made is superseded by an awareness of the materials of painting itself. This quality is even more marked in some of the smaller studies, and much the same can be said of the drawn versions. In Stonebreaker and other figures, Le Raincy the repeated movement of the conté crayon across the surface of the paper allows the figures to appear as though submerged within the densely-marked surface. ${ }^{53}$

That our attention is in part directed to the surface of these works and to the artistic labour involved in their making might suggest that Greenberg's diagnosis holds some water, that Seurat is more interested in formal questions than in stonebreakers. But in each image the figure or figures are still clearly present, still declaredly the subject of the picture. Or perhaps it would be better to say that it is their partly obscured presence that constitutes the subject of these images: as with Ruins of the Tuileries, we sense that what we see is also to some degree occluded. And as with the remains of the Tuileries Palace, at stake here is the question of memory. The stonebreakers - and with them the memory of Courbet - seem not quite graspable, like a spectre hovering behind the surface that cannot quite be brought into focus. The works' relationship to the histories upon which they touch, histories having to do both with radical politics (Socialism and the events of the Commune, with each of which Courbet was unavoidably associated) and with an earlier avantgarde tradition of politically engaged painting (with which Courbet was equally inextricably associated), is thus decidedly not one of straightforward affiliation. ${ }^{54}$ What these images bespeak is less the desire to resurrect Courbet than the recognition of his part-forgotten status. Which is to say that the shift towards an attention to surface, though it might appear to downplay the pictures' subjects in favour of formal properties (as Greenberg would argue), might more accurately be characterised as an index of - even a foregrounding of - the Third Republic's historical amnesia. 


\section{Naturalism in Suspension}

Again we must be careful not to attribute too fixed a meaning to images that are opaque not merely at the level of vision but also at that of interpretation. But again the resonance with the politics of forgetting in the Third Republic seems unmistakeable, as does the fact that this is in part figured through an analogous uncertainty in the artist's relationship to the pictorial past. What Courbet's legacy meant, to what degree he was available as a model, whether or not he could be recalled (in both senses: remembered and brought back into play): these are the questions posed by the stonebreakers images.

I want now to suggest that the uncertain relationship to artistic tradition - and specifically to earlier variants of naturalism - is apparent not merely in the reference to a theme unavoidably associated with Courbet but also in the repeated dabs, or taches, of Seurat's brush. This technique, I will argue, was itself marked by memory. If the partial occlusion of the burnt-out palace and of the labour of the stonebreakers allowed his work simultaneously to recall and forget and thus to speak to the Third Republic's amnesiac drive, the surface of iterated taches that screens history in this doubled sense was itself suspended between past and present, between memories of the politics of naturalist painting and the evanescence of this politics in the early 1880s.

That Seurat's work situated itself in relation to the naturalist tradition broadly understood - which is to say, to the strain of French painting that took as its central task the examination of the appearance of the world and that included among its ranks Courbet as well as Manet and the impressionists ${ }^{55}$ - is clear both from his subjectmatter and from his use of the tache, whose association with naturalism, and specifically with Manet, had been firmly established ever since Émile Zola’s foundational critical texts of the mid-1860s. (In 1866, for example, Zola had described the tache as Manet's great trademark: 'All of his being compels him to see in taches, in simple and energetic patches'. ${ }^{56}$ )

It is undoubtedly significant, then, that to invoke naturalism was to conjure a tradition that, like the Commune and Courbet, was itself somewhat in abeyance. Not that naturalism was being actively suppressed: if anything, it was on the rise - or at least an officially-sanctioned version of it (Bastien-Lepage and his ilk) was being enthusiastically promoted by a succession of Third Republic administrations. ${ }^{57}$ But 
naturalism's original proponents - most notably Zola - were unsure about these insipid variants and saw naturalism as being in suspension around 1880 .

This was very different from how Zola had earlier characterized Manet and his fellow naturalists. In his first extended foray into art criticism in 1866 he had described their work precisely as a living art unencumbered by the deathly grip of the past and thus entirely unlike the inert array of classicizing epigones haunting the Salon (recall Marx's optimistic characterization of the Commune as living truth opposed to the spectres at Versailles). At this time he foresaw great things for naturalism, confidently predicting that even if Manet was not yet appreciated, in the future 'our sons ... will go into ecstasies in front of his canvases.' 58

By 1879 he was less convinced. He was concerned in part by the fact that the blond tones and technical procedures of Manet's art were increasingly being adopted as a fashionable style by academically trained artists. ${ }^{59}$ Naturalism, that is to say, was already haunted by its own epigones (recall Marx’s reluctant acknowledgement of the Commune's failure to exorcize the ghosts of the past). More worryingly, even naturalism's leading practitioners seemed unable to produce the great paintings Zola by now expected to have seen. Manet himself was the primary cause for concern: 'If the technical side of his work equaled the correctness of his perceptions, he would be the great painter of the second half of the $19^{\text {th }}$ century' (my emphasis). ${ }^{60}$ But his canvases were too often 'imperfect and of uneven quality'; he remained merely a 'pupil.' 61 Zola wrote much the same of other naturalists - the impressionists, for example, were 'at fault in their technical inadequacy . . . one fears that they only prepare the way for the great future artist whom the world awaits' - and he concluded his argument in decidedly messianic terms: 'The stage is set for a painter of genius. ${ }^{62}$ In subsequent years the trope of the naturalist genius-to-come became something of an idée fixe for Zola, though as time passed he would grow increasingly pessimistic about whether the messiah would ever arrive. ${ }^{63}$

If Zola was disillusioned with the state of painting around 1880, this was for him not merely an artistic question. It was also closely tied to his views on contemporary politics. In the 1860s he had explicitly linked the deathliness of official art to the hypocrisy and artificiality of the Second Empire. In an article written in 1868 for the liberal weekly La Tribune, for example, he suggested that the venality of a blandly classicizing sculpture of Venus commissioned by Napoleon III revealed 
both the moral turpitude and the lack of vitality of the Empire. ${ }^{64}$ From this he proceeded to a general critique of the regime's promotion of the sham and the hollow. The imperial administration, he noted, 'talks loudly about its love for the arts. The truth is that the Second Empire will allow neither a great painter, nor a great sculptor, nor a great writer. The only artists that they really encourage are M. Haussmann's masons. The whole city has been given to them, and they have made of it a city of plaster, cardboard-stone, and fake marble. ${ }^{65}$ With the insipid depravity of the Emperor's Venus and the lifeless inauthenticity of his refashioned capital taken as indices of the failings of the imperial government, those rare artists who escaped this condition, most notably the naturalists, were seen as precursors of a better age: 'The democratic age that we are entering [Zola hoped] will require a virile art. ${ }^{, 66}$ Thus during this period Zola regularly described Manet as having 'a powerful hand. ${ }^{\text {'67 }}$

When the Third Republic arrived, however, it did not bring with it the freedoms Zola had assumed would flow naturally from republican democracy. Instead it continued the repression practiced by Napoleon III both politically and artistically. On the political level, the suppression of the Commune was the first great disappointment. Although Zola had been ambivalent about the activities of the Commune, he decried the government's brutality during the semaine sanglante, penning a graphic account of the aftermath: 'I managed to take a walk in Paris. It is atrocious. . . . I want simply to tell you about the piles of corpses that were stacked on the bridges. No, never will I forget the dreadful anguish that I experienced in front of this heap of bloody human flesh thrown at random on the towpaths. . . What a dismal charnel-house. ${ }^{68}$

On an artistic level, Zola's disappointment centred on cadavers of a different kind: the deathly epigones of academicism that the new administration continued to promote, now joined by naturalism's own belated imitators. After a decade he lost patience. In 1879 he lamented the jury's ongoing rejection of Manet and the impressionists. ${ }^{69}$ The following spring he compared the continued official support for classicism in contemporary literature to the attachment to antiquity in 1789 (like Marx, he was keenly aware of the contradiction between the Revolution's rhetoric of new beginnings and its re-use of earlier styles) and grumbled that the Third Republic resembled all other administrations in clinging to tired artistic formulae over which it felt able to exercise control. ${ }^{70}$ Two months later he repeated the complaint that the 
impressionists were being suppressed by the government and noted with regret that Monet and Renoir had given up the fight and returned to the Salon. ${ }^{71}$ All the more reason for his gloomy diagnosis of art c.1880 and for his increasing pessimism as to whether the long-awaited naturalist genius would yet arrive.

Zola's disenchantment with the Third Republic makes evident that the suspended moment he described in the arts was also a political suspension. In the 1860s he had taken the clear sightedness of naturalism to be resonant with a protorepublican outlook, one that aligned itself with a democratic take on the facts of the world. This argument could still be voiced in the mid 1870s when Stéphane Mallarmé aligned the Third Republic’s 'universal suffrage' (he failed to mention the limits to this 'universal': French women would not be given the vote until 1944) with the work of Manet and the impressionists: 'A parallel is found in artistic matters, the way being prepared by an evolution which the public with rare prescience dubbed, from its first appearance, 'intransigeant', which in political language means radical and democratic. ... [T]o day [sic] the multitude demands to see with its own eyes; and if our latter-day art is less glorious, intense and rich, it is not without the compensation of truth, simplicity and child-like charm. ${ }^{72}$ By the early 1880s Zola was less convinced by such arguments (Mallarmé’s move towards ever more opaque poetic forms suggests that he, too, became increasingly sceptical about the idea of democratic naturalism). The weakened state in which Zola considered naturalism to find itself c.1880 was the corollary of the parlous condition of the Third Republic, caught up in its attempt to forget the past - the only-ever partially successful amnesiac drive - and unable to move forward (at least in Zola's eyes) into a properly republican future. ${ }^{73}$

\section{The Dialectics of the Tache}

The problem with naturalism, then, was seen by Zola as being in part specific to the particular history of the Third Republic. But only in part. For Zola had long suspected that naturalism contained within itself - and specifically in its central pictorial device, the tache - the seeds of its own destruction. That destruction lay in the direction of what would later be called abstraction: the process by which the tache ceased to call to mind referents in the world (the appearance of light, say, or the way 
in which the eye perceived it) and began instead to assert its own presence, as mark and as painterly matter, on the surface of painting.

As I say, Zola had long been aware of the double aspect of the tache, though in the early years he for the most part skirted around the issue. When he wrote in 1867 that, for Manet, '[a] head placed against a wall is no more than a more-or-less white tache on a more-or-less grey ground', it was primarily to bolster the argument that the artist's goal was to capture the appearance of nature. ${ }^{74}$ The tache, he maintained, was true to how the world actually looks: in Manet's work 'the strict observation of the law of values' generated 'an ensemble of accurate and delicate taches which, from a few feet, give the picture a striking relief. ${ }^{75}$ It was also true to the artist's personal vision: 'The whole personality of the artist consists in how his eye is organized: he sees blond, and he sees in masses. ${ }^{\text {,76 }}$

Latent within Zola's account, however, was the contrary argument: that the tache was associated not with nature but with a turn away from mimesis and toward purely formal interests. ${ }^{77}$ We hear this already in the claim that a head becomes nothing more than a tache. It becomes more pronounced in the observation that Manet 'is only guided in his choice by the desire for beautiful taches, for beautiful oppositions.' 78 It is clearest, though, in Zola's account of Olympia [fig. 12], where he vacillated between the claim that the picture was true to nature - 'the painter has proceeded as nature herself proceeds, by clear masses, by broad areas of light ${ }^{79}$ - and an implicit acknowledgement that certain aspects of the image were determined not by the demands of vision but by those of form:

You needed a naked woman, and you have chosen Olympia, the first to arrive; you needed clear and luminous taches, and you inserted a bouquet; you needed some black taches, and you placed in a corner a negress and a cat. What does all this mean? You hardly know, nor am I any the wiser. But me, I know that you have admirably succeeded in making the work of a painter, a great painter, I want to say in translating vigorously and in a specific language the truths of light and shadow, the realities of objects and creatures. $^{80}$ 
To write that 'il vous fallait une femme nue' allowed for the artist's interest in the subject, but to write that 'il vous fallait des taches claires' and 'des taches noires' was to argue that Manet had a formal interest in - an aesthetic taste for - flat areas of light and dark in and of themselves, and that he introduced content (bouquet, servant, cat) simply to satisfy this interest. This claim was in part tactical: Zola sought to downplay the importance of subject matter in order to defend the artist against the charge that he had deliberately set out to shock (his particular concern was to refute the association of Manet's work with the poetry of Charles Baudelaire) ${ }^{81}$ Thus he did not cleave to this formalist position for long: the passage closes with the more typically Zola-esque claim that this was the work of a great painter because it translated, in a personal language, the truths and realities of the object-world and its appearance. Nevertheless, in the preceding sentences he had let the (black) cat out of the bag, identifying an anti-mimetic logic within naturalist painting.

In 1867 abstraction was the latent content of Manet's tache, one that Zola recognized only to disavow. As the years passed it would increasingly come to the fore. Consider the remarkable meditation on the dual nature of the tache that Manet crafted sometime towards the end of the 1870s. Young Woman in a Round Hat [fig. 13] positions its subject in the centre of the canvas, facing left, her deep blue jacket and black hat and gloves contrasting sharply with the pale background. In her gloved hand she holds a cane, and what may be a coat is draped across her right arm, either in preparation for an imminent departure or having just been removed. Behind her the indistinct background reveals details of foliage and blue sky seen underneath vertical smears of semi-transparent off-white paint that the artist has dragged across the surface, half hiding what he had earlier delineated.

On one level this backdrop is a typically brilliant piece of illusionism, conjuring up the view onto a garden through a diaphanous net curtain - a translucent screen that rhymes with the veil worn by the woman. But Manet leaves clues that suggest that such emphatic brushwork can as easily refuse vision. Note the dabs and dashes of green paint added on top of the white background. Appearing on the near side of the curtain, these marks make little mimetic sense, undoing the illusion that the artist had just created. The smears of off-white paint are revealed as mere paint, as a screen of material pigment rather than a gauzy veil. 
That Manet was aware of this double reading is suggested by the even more telling detail of the dark tache just to the left of the woman's eye. On one level, this is once again an astonishing piece of illusionism, evoking the suddenly opaque quality of the veil as it angles back into space and leaves us unable to see through its myriad perforations. But this is also the tache as obstruction. The veil becomes impenetrable to vision, screening the world off from the woman's view (she is left blinded, as it were) and also partly hiding her eye from the viewer. ${ }^{82}$ The tache thus operates here to invoke but equally to refuse vision - both the sitter's and the viewer's - suggesting that Manet was interested in those elements implicit in his earlier work that Zola had for the most part repressed, and making clear that when the tache operated as formal element it did so at the expense of representation. Attention to form - to the abstract qualities of the work - stands in an always tense relation to painting's representational task. $^{83}$

\section{Screening History}

It was not only vision, of course, that was called into question. Politics was also part of the equation, as Zola's thoughts on naturalism's faltering condition c.1880 make plain. Just as the tache lost its association with the ideal of a clear-sighted vision of the world, so too under the Third Republic were the democratic and republican connotations of naturalism (as previously articulated by Zola and Mallarmé) becoming less certain. For Seurat to engage with naturalism in the early 1880s - and specifically with Manet's trademark tache, perhaps filtered through impressionism - was thus to engage with a movement that in the eyes of its foremost supporter was doubly in suspension: artistically, waiting for the future genius; politically, shorn of its earlier ideological clarity. What, then, did he make of this inheritance?

It seems fair to say that Seurat pushed further into relief the dualism of the tache predicted by Zola and increasingly enacted by later Manets such as Young Woman with a Round Hat. Consider, for example, the area of brown pigment above the central woman's knees in The Stonebreakers, Le Raincy. Indicating her posture telegraphically but meticulously by suggesting an angling back into depth of her thighs that mirrors what we take to be the forward tilt of her torso, this is the tache as breathtakingly precise and economical mimesis, keeping in view the memory of what 
it had earlier been. Yet at the same time the repetition of the weave of brushstrokes in the ground to either side of the woman locks this same area into the surface, forcing it back into alignment with the vertical plane of the wooden support. This is the tache as formal element, and it begins to become the dominant logic of the image. Marks that gesture towards representational content - which is to say, marks that recall the naturalist project - come more and more to constitute a screen that seems paradoxically to hide that content (paradoxically, because what is represented is present only in that screen). The central woman's face is particularly revealing (or concealing, at it were) in this regard. Certain details can perhaps be discerned: the structure of the nose, the shadows around the eye-sockets, perhaps even a mouth. But these lingering indications are less emphatic than our sense of the face as a single patch on the surface. To paraphrase Zola: the face is only a more-or-less brown patch on a more-or-less black ground.

We might note in this regard Seurat's remarkable image of a young boy in blue [fig. 14], probably a peasant but sometimes identified as a jockey (such uncertainty is itself symptomatic). We are reminded of innumerable naturalist precedents, endless peasants waiting patiently for their likeness to be recorded. But the repeated taches keep the figure at a distance, and it is in the boy's face that what is at stake is most clearly felt. Seurat has pulled the brush across the face, effacing its specificity and concreteness: defined cheekbones, jaw, and so forth remain visible beneath the broad strokes, but are rendered barely legible. The image, we might say, is rendered mute, just as the boy, his mouth occluded, remains silent. ${ }^{84}$ But it is sight, of course, that is here rendered inoperative: the image offers us the facts of vision but also builds blindness into its own operation as brushstrokes align more and more obediently the one with the next in an impenetrable screen. Where Manet invoked the tache as a moment of sightlessness in Young Woman, here the entire image is at it were veiled: Manet's woman might find her sight partly blocked, but with Seurat it is the beholder who cannot see clearly.

If Seurat thus made of the tache a device that was both backward- and forward-looking, recalling naturalism's mimetic foundations whilst simultaneously foregrounding the abstraction latent within its central device, his work also pushed firmly into view the fact that the status of the tache (and of naturalism more broadly) was closely tied to questions of politics. As we have seen, several of his images of 
the early 1880s twin the part-naturalist, part-abstract tache with subjects that themselves had to do with memories of a politics half-forgotten, half-suppressed (the skeletal ruins of the Tuileries and the subject matter of an earlier tradition of radical naturalism in the stonebreakers). And just as the significance of those subjects is hard to pin down, so too is the relationship between Seurat's tache and its forebears. His technique is in part naturalist and thus in part an invocation of an earlier tradition associated with liberal politics (recall that for Zola the tache's ability to capture the appearance of things and to embody the artist's personal vision was the index of a proto-republican vitality opposed to the anemic venality of the Second Empire). But his work is equally a refusal - or a rendering blank - of that same tradition. For Seurat, the tache is both representation and not representation. Mimesis and its ideological connotations are thus held in suspension.

I said at the outset that Ruins of the Tuileries looks forward and back. We can now say that the way in which that image (like the series of stonebreakers and Young Peasant in Blue) looks forward, namely in its emphasis on pictorial structure and the rhyming of repeated dabs of pigment across the surface, is itself double-sided, shot through by memory. If the screening of the ruins foregrounds the amnesiac drive of the Third Republic, the technical device that performs that occlusion is equally suspended between an earlier pictorial radicalism and the act of forgetting it. Here it is an internal dynamic, one that takes place within the tache itself, suspended as it is between representation and what Zola had long suspected it might become, mere abstraction. In Seurat's work the tache is thus in every sense a screen, for a structure of amnesia or disavowal is built into the technique itself. And crucially, this condition is historically specific, tied to a moment when the naturalist inheritance as a whole - along with its politics - was in suspension. What we see here, pace Greenberg, is not a refusal of the welter of ideological struggle. Seurat's early work is instead marked through and through by that struggle, embedding a specific ideological formation - the Third Republic's amnesiac drive - within the pictorial logic of its very technique.

Constituting a painted surface from reiterated units would be central to Seurat's later work: neo-impressionism is in essence a screen of variegated dots, one that Hubert Damisch has linked to a kind of blindness. The displacement of outline by an array of 'grains', as Damisch terms them, undermines earlier conceptions of the 
surface as a projective screen. ${ }^{85}$ Such a blinding would be central to the emergence of abstraction in the early twentieth century, as repeated dots, facets, and so forth displaced mimesis. The early works by Seurat that we have considered were a first step in this direction, and crucially they make clear that, although the embedding of the tache within a densely-woven surface may answer in part to Greenberg's account, the balance between representation and its suppression in the works we have considered constituted not a withdrawal from politics but a figuring of Third Republic politics both in the half-occluded subjects of these images and in the facture that performs that occlusion.

Seurat's work - and perhaps more broadly a nascent abstraction - was thus marked by politics from the start. So too was the city in which it emerged. In 1882 the ruined edifice of the Tuileries was replaced by an empty grid comprising formal gardens and a featureless thoroughfare in an effort to excise the memory of the building from the capital's collective memory. But the demolition of the ruins never fully wiped the slate clean. What was occluded remained as a spectre haunting the scene, with the very name of the thoroughfare - rue des Tuileries - necessarily calling to mind what had once stood there. ${ }^{86}$ The aesthetics of the formal garden, all structure and uniform rhythm, never fully displaced lived political history. So, too, in Seurat's work. Representation may begin to cede to pictorial concerns centred on the grid-like structure of the surface weave, the iterable mark may open to door to abstraction, but the new dispensation remains haunted by the old.

\section{Notes}

I am indebted to audiences at the Institute for Advanced Study, Princeton, and at the Universities of Oxford and Nottingham for invaluable feedback on earlier versions of this paper. The anonymous readers of Art History offered very helpful comments and suggestions for which I am most grateful. My research has been supported by the Department of Art and Archaeology at Princeton University, by a Leverhulme Research Fellowship, and by St John’s College, Oxford.

\footnotetext{
${ }^{1}$ If, as Richard Wollheim has argued, all pictures have the quality of 'twofoldness', with the viewer simultaneously aware of the arrangement of forms on the surface
} 
(what Wollheim calls the 'configurational aspect') and of the referential content of those forms (the 'representational aspect'), it seems fair to say that Seurat's image tips the balance at least partly towards the former, and certainly further in that direction than was the norm in French painting of the period. See Richard Wollheim, Painting as an Art, London, 1987, 46-47 and 72-73

${ }^{2}$ On Seurat's use of unprimed hardwood panels, see Jo Kirby et al, 'Seurat's painting practice: theory, development and technology', National Gallery Technical Bulletin 24, 2003, 18.

${ }^{3}$ Clement Greenberg, 'Seurat, science, and art: review of Georges Seurat by John Rewald', The Nation, 25 Dec. 1943; rpt. in John O’Brian, ed., Clement Greenberg: The Collected Essays and Criticism, Chicago and London, 1986-1993, 4 vols, 1:168. For an earlier reading of Seurat as an artist more interested in the formal properties of his paintings than in the subjects they represented, see Roger Fry, 'Seurat,' in Transformations: Critical and Speculative Essays, London, 1926, 188-96; and 'Seurat’s La Parade,’ Burlington 55, Dec. 1929, 289-93.

${ }^{4}$ Clement Greenberg, 'Avant-garde and kitsch', Partisan Review, 6, Fall 1939; rpt. in O’Brian, Clement Greenberg, 1:7.

${ }^{5}$ Greenberg, 'Avant-garde and kitsch', in O’Brian, Clement Greenberg, 1:7-8.

Greenberg would later acknowledge that the Neo-Impressionists 'were the first after Courbet to join avant-gardism to radical politics’, but he emphasized that Seurat, unlike his pointillist colleagues, had never 'professed anarchism' (Clement Greenberg, 'Review of Camille Pissarro: Letters to his son Lucien, edited by John Rewald', The Nation, 24 Jun. 1944; rpt. in O’Brian, Clement Greenberg, 1:214-15). Seurat, in other words, safely exemplified the putative move from politics to formalism.

Greenberg's view of Seurat chimed with that espoused a few years earlier by the late master's closest colleague, Paul Signac, in a 1935 text that would later be added to a posthumously updated edition of his extended historical and theoretical defence of divisionism, D’Eugène Delacroix au néo-impressionnisme. Signac argued that subject matter was far less important than 'the aesthetic and formal forces of organization, harmony and materials. ... Seurat so little valued the subject that he declared to his friends: "I could just as well have painted, in a different harmony, the 
battle of the Horatii and the Curiatii [instead of Sunday promenaders on the Grande Jatte]”' (D’Eugène Delacroix au néo-impressionnisme, ed. Françoise Cachin, Paris, 1964, 153-54; 'les forces esthétiques et plastiques d’ordonnance, d’harmonie, de matière. . . . Seurat tenait si peu au sujet qu'il déclarait à ses amis: “J’aurais aussi bien peint, dans une autre harmonie, le combat des Horaces et des Curiaces”'). Earlier, however, Signac had offered a far more nuanced account of the relative importance of subject-matter and technique. In 'Impressionists and Revolutionaries,' published anonymously in La Révolte in 1891, he spoke approvingly of Seurat's formal innovations (the artist, he suggested, was one of 'the pure aesthetes, revolutionary by temperament, who, distancing themselves from the beaten path, paint what they want, as they feel it, and very often give, unconsciously, a solid blow of the pick-axe to the old social edifice, which cracks and crumbles, worm-eaten, like an ancient disused cathedral'); but he was equally positive about Seurat's socially engaged 'synthetic representation of the pleasures of decadence: balls, chahuts, circuses' ('Impressionnistes et révolutionnaires,' La Révolte, 13 June 1891, pp. 3-4; rpt. in 48/14: La Revue du Musée d'Orsay, vol. 12, Spring 2001, p. 100-101; 'les purs esthètes révolutionnaires par tempérament, qui s’éloignant des sentiers battus, peignent ce qu'ils veulent, comme ils le sentent et donnent inconsciemment, très souvent, un solide coup de pioche au vieil édifice social qui craque et s’effrite vermoulu ainsi qu’une ancienne cathédrale désaffectée . . . représentation synthétique des plaisirs de la décadence: bals, chahuts, cirques’. Signac, 'Impressionnistes et révolutionnaires'). For discussion, see Alastair Wright, 'Mourning, painting, and the Commune: Maximilien Luce’s A Paris Street in 1871,' Oxford Art Journal 32, 2, summer 2009, 232-35.

${ }^{6}$ See inter alia Jodi Hauptman's observation that in the early drawings 'the image alternates between a picture and a screen or scrim of textured marks' (Jodi Hauptman et al, Georges Seurat: The Drawings, exh. cat., New York, 2007, 12); Anthea Callen's suggestion that Seurat invites us to lose ourselves in the image whilst retaining an awareness of its material means (Anthea Callen, 'Hors-d'oeuvres: Edges, boundaries, and marginality, with particular reference to Seurat's drawings', in Paul Smith, ed., Seurat Re-Viewed, University Park, Pa., 2009, 17); and Richard Shiff’s rather more Greenbergian claim that in his early paintings Seurat 'attended to the 
integrity of his physical medium of oil paint on canvas' (Richard Shiff, 'Seurat distracted', in Hauptman et al, Georges Seurat, 26). Shiff makes the reference to Greenberg explicit in 'Grave Seurat', in Smith, ed., Seurat Re-Viewed, 175. Paul Smith has written persuasively (though his suggestion as to how we might read this quality is very different from mine) of how Seurat's neo-impressionist paintings also seems to create a 'veil' between the viewer and the image (Paul Smith, “'Souls of Glass”: Seurat and the Ethics of “Timeless Experience”,' in Smith, ed., Seurat ReViewed, 210).

${ }^{7}$ Greenberg, ‘Avant-garde and kitsch’, in O’Brian, Clement Greenberg, 1:7-8.

${ }^{8}$ Most writers on Seurat would agree that Seurat's subsequent development refutes Greenberg's claim: it would be hard to justify the view that Bathers at Asnières or Sunday Afternoon on the Island of La Grande Jatte have nothing to do with 'ideological struggle' in one form or another (though in what form, exactly, is much debated). Less attention has been paid to the politics of the early work, however, and very little to how an incipient abstraction might itself be tied to the politics of the Third Republic. Those who do link Seurat's early work to a broadly political context interpret the way in which form tends to mask his subjects as exemplifying in a general sense a typically naturalist detachment in contrast to an earlier tradition of empathetic realism (see Robert L. Herbert, Seurat and the Making of La Grande Jatte, Chicago, 2004, 37). Seurat's attention to formal properties in his later work is often read as evidence of his interest not in politics but in aesthetic questions deriving from the academic tradition and/or symbolist experiments with rhythm, musicality, and so forth (see inter alia Paul Smith, Seurat and the Avant-Garde, New Haven and London, 1997; and Neo-Impressionism and the Dream of Realities: Painting, Poetry, Music, exh. cat., Washington, D.C., 2014).

${ }^{9}$ Much of the most interesting work on the relationship between modernism and the trauma of the Commune is found in studies not of the period's art but of its literature. Kristin Ross's study of Rimbaud is exemplary (The Emergence of Social Space: Rimbaud and the Paris Commune, Minneapolis, 1988). See also Daryl Lee, 'Rimbaud's ruin of French verse: Verse spatiality and the Paris Commune ruins', Nineteenth-Century French Studies, 32, 1-2, Fall-Winter 2003-04, 69-82. 
${ }^{10}$ This article draws on material from an ongoing book project on the aftermath of the Commune in which I examine Seurat's early work alongside his major paintings of the mid to late 1880s and the work of his neo-impressionist colleagues. The broader argument of the book is that to understand the emergence in the 1880s of various strains of what we now label as modernist painting we must consider them as, so to speak, the death-throes of naturalism, and that to understand the deathliness of naturalism we must look closely at the politics of the French Third Republic and the traumatic memory of the Commune.

${ }^{11}$ A wide range of early abstract and proto-abstract artists went through a broadly neo-impressionist phase early in their development. Among many others we can cite Robert Delaunay, Francis Picabia, Piet Mondrian, Wassily Kandinsky, and most of the Italian futurists.

For a recent and relatively comprehensive account of the emergence of abstraction in European and American art, see Inventing Abstraction, 1910-1925: How a Radical Idea Changed Modern Art, exh. cat., New York, 2012. The catalogue has little to say about Seurat's role as precursor - perhaps surprisingly, given that Alfred Barr's famous flow chart 'The development of abstract art', which is invoked as one of the inspirations for the exhibition, gave neo-impressionism a prominent place as one of the sources of fauvism, cubism, and futurism. The longer prehistory of abstraction, again with little attention paid to Seurat and neo-impressionism, is examined in Aux Origines de l'Abstraction, 1800-1914, exh. cat., Paris, 2003. Paths to Abstraction, 1867-1917, exh. cat., Sydney, 2010, gives fuller attention to Seurat and the neo-impressionists (see in particular Terence Maloon, 'Towards abstraction,' in Paths to Abstraction, 23; and Maloon, 'Paths to abstraction, 1867-1917,' in Paths to Abstraction, 173-74). Georges Roque has argued that Seurat's neo-impressionist technique revolved around the realization that artistic signs were abstract elements i.e. iterable units - and that this was the artist's most important contribution to subsequent modernism (Georges Roque, “Seurat and Colour Theory,” in Smith, ed., Seurat Re-Viewed, 59).

12 Seurat's oeuvre was, of course, just one point of origin among many for the abstraction to come. Cézanne, engaged simultaneously in a very different exploration 
of the boundary between representation and abstraction, was another, and it would be easy enough to extend the list almost indefinitely.

13 Jean-Marie Bruson, 'Iconographie du château des Tuileries après l’incendie’, Monuments historiques, 177, Sept.-Oct. 1991, 34; and Kirk Varnedoe, 'The Tuileries Museum and the uses of art history in the early Third Republic', in Francis Haskell, ed., Saloni, gallerie, musei e loro influenza sullo sviluppo dell'arte dei secoli XIX e $X X$, Acts of the $24^{\text {th }}$ International Congress of the History of Art, Bologna, 1979, 6364.

${ }^{14}$ For details of the political debates and decisions, see Emilie Michaud-Jeannin, 'Vestiges lapidaires', Monuments historiques 177, Sept.-Oct. 1991, 39-42; and JeanFrançois Pinchon, 'Charles Garnier et l'hypothétique', Monuments historiques 177, Sept.-Oct. 1991, 43-49.

${ }^{15}$ Michaud-Jeannin, 'Vestiges lapidaires', 41-42; Varnedoe, ‘The Tuileries Museum', 64-65.

${ }^{16}$ Few scholars have commented upon the image’s loaded subject. Richard Thomson is a rare exception, noting in passing that to paint the Tuileries was political without expanding upon this point (Richard Thomson, Seurat, Oxford, 1985, 64); see also Albert Boime, Art and the French Commune: Imagining Paris after War and Revolution, Princeton, 1995, 173. Seurat's painting is mentioned in passing in Bertrand Tillier's extensive and incisive analysis of how the Commune was (and was not) pictured both in its own moment and in later decades; La Commune de Paris: révolution sans images? Politique et représentations dans la France républicaine (1871-1914), 375-76.

For a compelling reading (though one that takes a very different approach to mine) of a painting of demolition in Paris made by one of Seurat's later colleagues, see Richard Thomson, 'Ruins, rhetoric and revolution: Paul Signac's Le Démolisseur and anarchism in the 1890s', Art History 36, 2, April 2013, 366-91.

${ }^{17}$ Seurat's artist friend Edmond Aman-Jean recalled him being labeled a Communard; see Georges Seurat, 1859-1891, exh. cat., New York, 1991, 378.

${ }^{18}$ Compare Jonathan Crary's analysis of Seurat's drawings of evacuated urban spaces (for example, in Place de la Concorde, Winter, 1882-83) as the negative image of revolution, an empty space where political theatre used to exist: ‘[M]ore than 
representations of anomie or class conflict,' he writes, Seurat's 'works are determined by a sense of the impalpability and evanescence of the social itself' (Suspensions of Perception: Attention, Spectacle and Modern Culture, Cambridge, Mass., 1999, 186).

${ }^{19}$ Meyer Schapiro had already very effectively criticised the idea that later nineteenth century painting predicted abstraction two years before Greenberg took this idea as one of his starting points in 'Avant-Garde and Kitsch'. See Meyer Schapiro, 'The nature of abstract art,' Marxist Quarterly 1, no. 1 (Jan.-Mar. 1937), 77-98; rpt. in Meyer Schapiro, Modern Art: $19^{\text {th }}$ and $20^{\text {th }}$ Centuries, New York, 1978, 185-211. Schapiro’s argument was intended as a rebuttal of Alfred H. Barr, Jr.'s ahistorical account of the development of abstraction in Cubism and Abstract Art, New York, 1936.

${ }^{20}$ The term 'abstrait' would be applied to Seurat's paintings from as early as 1887 when Félix Fénéon observed that the ‘uniform and as though abstract execution’ of the neo-impressionists allowed the coloured dots to merge into luminous masses when the viewer stepped back (he also insisted that the execution left intact the originality of the artists). See Félix Fénéon, 'Le Néo-Impressionnisme,' L'Art moderne de Bruxelles, 1 May 1887; rpt. in Félix Fénéon, Oeuvres plus que complètes, ed. Joan U. Halperin, 2 vols, Geneva, 1970, 1:74: ‘exécution uniforme et comme abstraite’. That Fénéon tied the 'comme abstraite' technique to the reproduction of light effects makes clear that he did not mean abstract in its common twentieth-century sense, i.e. nonrepresentational. The same is true of Paul Adam's use of the term the preceding year, when he applied it to impressionism as a whole (he included Seurat and his colleagues in this grouping). The impressionists, he suggested, reproduce 'the pure phenomenon, the subjective appearance of things. It is a school of abstraction. It escapes the error imposed on our thought by twenty centuries of dualist education, which imagined outside our senses the imaginary existence of an objective world. Modern philosophy abandons itself to a single substance, the phenomenon-idea'. Paul Adam, 'Peintres impressionistes,' La Revue contemporaine 4 (Apr.-May 1886): 542): 'le phénomène pur, l'apparence subjective des choses. C’est une école d'abstraction. Elle fuit l'erreur imposée à notre esprit par l'éducation de vingt siècles dualistes, qui créèrent hors nos sens l'existence d'un monde objectif tout imaginaire. La philosophie moderne se convertit à une substance unique, le phénomène-idée’. Paint what you 
see, not what you know: this injunction is, again, very different from later understandings of 'abstract' as non-representational.

${ }^{21}$ Karl Marx, The Civil War in France: Address of the General Council of the International Working-Men's Association, London, 1871; rpt. in Karl Marx, Frederick Engels: Collected Works, London, 1975-, 50 vols, 22:309-59. The text, written in English in London, drew on published accounts and eyewitness reports.

${ }^{22}$ Karl Marx, The Eighteenth Brumaire of Louis Bonaparte, in Karl Marx, Frederick Engels, 11:103-04. For Derrida's commentary, see Spectres of Marx: The State of the Debt, the Work of Mourning, and the New International, New York and London, 1994, 107-14.

${ }^{23}$ Marx, Civil War in France, 104; in Karl Marx, Frederick Engels, 22:341-42.

${ }^{24}$ Marx, Civil War in France, 95; in Karl Marx, Frederick Engels, 22:333.

${ }^{25}$ Marx, Civil War in France, 103; in Karl Marx, Frederick Engels, 22:341.

${ }^{26}$ Marx, Civil War in France, 86; in Karl Marx, Frederick Engels, 22:324. The $22^{\text {nd }}$ of January 1871 is the date of a demonstration seen as the precursor to the Commune. Workers and National Guards gathered in front of the Hôtel de Ville to demand the overthrow of the government; soldiers guarding the building opened fire on the demonstrators.

${ }^{27}$ Maxime Du Camp, Les Convulsions de Paris [1878-80], Paris, 1889, $7^{\text {th }}$ ed., 4 vols, 2:202-203.

${ }^{28}$ Daudet's remarks appeared in 1897 in response to a questionnaire on the Commune circulated by the anarchist art critic Félix Fénéon. Ernest Daudet, untitled entry in Félix Fénéon, 'La Commune’, La Revue blanche, 12, 1897, 254: 'rhetorique pompeuse et boursouflée'.

${ }^{29}$ On the difficulty of incorporating the Commune into 'the French national fiction,' see Kristin Ross, Communal Luxury: The Political Imaginary of the Paris Commune, London and New York, 2015, 4 and passim.

${ }^{30}$ See George Tersen, 'L’Opinion publique et la Commune de Paris 1871-1879,' Bulletin de la Société d'études historiques, géographiques et scientifiques de la région parisienne, 34, 1960: no. 106, 15-27; nos. 107-08, 26-36; no. 109, 25-30. A number of early accounts of the Commune are reprinted in Nicole Priollaud, ed., 1871: La Commune de Paris (Les Reporters de l'Histoire, no. 1), Paris, 1983. 
${ }^{31}$ On amnesties and the forgetting of the Commune, see Alain Dalotel, 'Deux amnisties pour oublier la Commune', in Répression et Prison Politiques en France et en Europe au XIXe siècle, Paris, 1990, 171-85; and Alice Bullard, Exile to Paradise: Savagery and Civilization in Paris and the South Pacific, 1790-1900, Stanford, 2000, 236-39.

${ }^{32}$ Quoted in Jules Castagnary, Gustave Courbet et la Colonne Vendôme: Plaidoyer pour un ami mort, ed. Bertrand Tillier, Tusson, 2000 [1883], 10: 'Il faut que vous fermiez le livre de ces dix dernières années, que vous mettiez la pierre tumulaire de l'oubli sur tous les crimes et tous les vestiges de la Commune et que vous disiez à tous qu'il n’y a qu'une France et qu'une République.'

33 Jules Vallès, 'Fraternité', La France, 7 July 1882; quoted Thomson, Seurat, 64.

${ }^{34}$ On Monet’s images of the Tuileries, see Tillier, La Commune de Paris, 374-75.

Other Impressionists were equally involved in occluding the memory of 1870-71. See André Dombrowski, 'History, memory, and instantaneity in Edgar Degas’s Place de la Concorde’, Art Bulletin 93, 2, June 2011, 195-219.

${ }^{35}$ On the painting's meaning and exhibition history, see Constance Cain Hungerford, 'Meissonnier's Siège de Paris and Ruines des Tuileries,' Gazette des Beaux Arts 6, 116 (Nov. 1990), 201-12.

36 ‘Au fond, la victoire semble s'en aller sur son char, elle nous quitte'; Exposition Jean-Louis-Ernest Meissonier (Paris, 1893), 6-7; quoted in Constance Cain Hungerford, 'Meissonnier’s Souvenir de Guerre Civile,' Art Bulletin 61, no. 2, June 1979, 277, n. 5.

${ }^{37}$ Hungerford, 'Meissonnier’s Siège de Paris,' 209.

38 Joseph [Guiseppe] de Nittis, Notes et souvenirs (Paris, 1895), 228; Varnedoe, 'The Tuileries Museum’, 67 and 68, n. 18. On a similar historical evasiveness in de Nittis's earlier painting of the Place de la Concorde, see Dombrowski, 'History, memory, and instantaneity', 214.

We might note that in 1882 the Ministère de l'Instruction Publique also purchased de Nittis’s Place des Pyramides. Unlike Place du Carrousel, this earlier picture insists on remembering. Emmanuel Frémiet's gilt bronze sculpture of Joan of Arc, commissioned by the government following the twin disasters of the FrancoPrussian War and the Commune and erected in 1874, is shown facing the ruins of the 
Tuileries and the as-yet-unrepaired pavillon de Marsan. Here we are closer to Meissonnier, though de Nittis gives more attention to the hopeful vision of life continuing despite the historical trauma. In 1882 his Place du Carrousel further suppressed the weight of the trauma in favour of everyday life.

${ }^{39}$ In the Gazette des Beaux-Arts Paul Lefort noted de Nittis's long-standing interest in 'the look of our streets, our quays, our squares, with their movement, their commotion, all their daily life, teeming and intense' and aligned his latest work with this enduring and innocent predilection: 'The Place du Carrousel, the ruins of the Tuileries forming a backdrop illuminated by the artist with strong sunlight, thus returns completely to the habitual manner of M. de Nittis: it is, above all, a Parisian spectacle’ (Paul Lefort, 'L’exposition nationale de 1883 (Deuxième article)', Gazette des Beaux-Arts, Nov. 1 1883, 399): 'l'aspect de nos rues, de nos quais, de nos places, avec leur mouvement, leur tohu-bohu, toute leur vie journalière, fourmillante et intense. . . . La Place du Carrousel, dont les ruines des Tuileries forment le fond et que l'artiste a éclairées d'un grand coup de soleil, rentre donc absolument dans la manière habituelle de M. de Nittis: c'est, avant tout, un spectacle parisien'. What we see here, Lefort insists, is mere spectacle, the scintillating panorama of modern life that de Nittis customarily offered his appreciative audience. That it was not the site but de Nittis's depiction of it that generated this neutrality is made clear from Lefort's very different response to Meissonnier's Ruins of the Tuileries, shown at the same exhibition. This, he informed his readers, was a picture motivated by 'a philosophical thought, rather than the mere love of the pictureseque' (Lefort, 'L'exposition nationale de 1883’, 398: 'une pensée philosophique, pluôt que le seul amour du pittoresque'). The inscription and other details made this clear, he suggested, though he did not specify what exactly he believed Meissonnier’s 'philosophy lesson’ to be; perhaps, given the desire for amnesia, such things were best left unsaid (Lefort, 'L’exposition nationale de 1883', 399: 'leçon de philosophie').

On de Nittis's (generally positive) reception in the French press, see Dominique Morel, 'De Nittis et la critique française: “Ce vaillant Napolitain de la rue Navarin”,' in Giuseppe de Nittis: La Modernité élégante, exh. cat., Paris, 2010, 26-33. 40 The memory of the Commune was negotiated in similarly (and perhaps deliberately) ambiguous fashion in a range of visual media. On one particularly 
telling example, the painted sign for Montmartre’s Lapin Agile, See Howard Lay, 'Pictorial acrobatics,' in Montmartre and the Making of Mass Culture, ed. Gabriel P. Weisberg, New Brunswick, NJ, 2001, 145-79.

${ }^{41}$ The shading on the ruins seems inconsistent with what we know of their structure. Between the central set of windows and those to the right darker and lighter brown tones alternate in roughly rectangular patches that undo a sense of stable illumination. In the two lower tiers the darker brown is to the right; above it is to the left, suggesting paradoxically both that the area between the windows is angled at its midpoint (whereas in fact it was a broadly planar section of wall) and that the light falls from different directions on the upper and lower sections. The effect is reminiscent of the similarly inconsistent illumination of flat walls in contemporaneous works by Cézanne - as, for example, seen in Houses in Provence: The Riaux Valley near L'Estaque, c. 1883 (National Gallery of Art, Washington, D.C.).

There may, in fact, be a logical explanation of the odd pattern of light and dark on the ruins: namely, that we are in fact looking at the remnants of the soot that still adhered to the building many years after smoke and flames had scarred its façade. But our uncertainty as to the referent of the darker areas - soot or shade - is itself significant. Again, the painting renders uncertain what it is that we are looking at even as it keeps the ruins fully in view.

We might note in addition that the indistinct quality of the depicted scene is amplified by the decidedly even lighting. We sense that the sun is shining, but we would be hard pressed to say where in the sky it sits, and there are no consistently cast shadows to lend volume either to the ruined façade or to the foreground objects. Even where differentiated shading appears, as in the foliage at the left, the result is somewhat confusing: the darker area hollows out the tree's volume and makes its near side appear oddly concave.

42 The seven paintings clearly showing stonebreakers are Bineur (Casseur de pierres), c. 1882 (cat. no. 30 in César de Hauke, Seurat et son oeuvre, Paris, 1961, hereafter DH); Casseur de pierres (Paysan au travail), c. 1882 (DH 31); Piochant, c. 1882 (DH 32); Casseur de pierres, c. 1882 (DH33); Two Stonebreakers (titled Deux paysans aux champs by de Hauke), c. 1882 (DH35); Casseur de pierres (Le Tas de pierres), c. 1882 (DH36); The Stonebreakers, Le Raincy (titled Casseurs de pierres by de 
Hauke), c. 1882 (DH38). An eighth painting sometimes identified as stonebreakers is Bûcherons (so-titled by de Hauke; in fact the three men seem to be driving piles rather than cutting wood or breaking stones), c. 1882 (DH39). The four drawings are Stonebreaker and other figures, Le Raincy (titled Casseur de pierres et autres personnages - Le Raincy by de Hauke), dated c. 1881 by de Hauke, though I would place it later (see following footnote) (DH463); Casseur de pierres (Le laboureur Jardinier - Terrassier), c. 1883 (DH555); Casseur de pierres, debout, de dos, c. 1883 (DH556); and Faneur (Casseur de pierres), c. 1883 (DH557).

${ }^{43}$ Herbert suggests that the drawing may have been a preparatory study, but dates it as early as 1879-81 (Georges Seurat, 1859-1891, 27), which is to say before most of the small painted and drawn stonebreakers. The regular weave of looping crayon strokes, which closely resembles the drawings of 1882-1883, strongly suggests that Stonebreaker and other figures is the culmination of his exploration of the theme. For details of the extensive adjustments Seurat made to the drawing, further suggesting that it was a preparatory study, see Shiff, 'Grave Seurat', 39.

${ }^{44}$ While Seurat's painting is assumed to be forward-looking, his drawings are more often linked to historical precedents. Again, however, the connection to Courbet is largely ignored. Robert Herbert's characterization of the drawings as part a 'romantic naturalist' tradition running from Rembrandt and Goya to Daumier and Millet continues to hold sway in the literature, with Courbet mentioned only in passing (if at all) and Millet presented as Seurat's primary source. See Herbert, Seurat's Drawings, passim; Georges Seurat, 1859-1891, 34 and 128 (where a stonebreaker image is linked to Millet with no mention of Courbet); Robert L. Herbert, Seurat and the Making of La Grande Jatte, Chicago, 2004, 27-28; John Leighton and Richard Thomson, Seurat and the Bathers, London, 1997, 23; and Marina Ferretti Boquillon, Seurat et le dessin néo-impressionniste, exh. cat., Paris, 2005, 10. That Millet was an important source for Seurat is not in question: his images of agricultural workers clearly invoke the earlier artist. But Courbet was, at least for a moment, an equally important source.

One of the few considerations of Seurat's debt to Courbet and of the relevance of Courbet's rehabilitation in the early 1880s is found in Michael F. Zimmermann, 
Les Mondes de Seurat: son oeuvre et le débat historique de son temps, trans. Jérôme Ferry, Solange Schnall and Karin Fanny Willems, Paris and Antwerp, 1991, 89-94. ${ }^{45}$ Exposition des oeuvres de Gustave Courbet à l'École des Beaux-Arts (Mai 1882), exh. cat., Paris, 1882. For details of the purchases and exhibition, see Gonzalo J. Sanchez, Organizing Independence: The Artists Federation of the Paris Commune and its Legacy, 1871-1889, Lincoln, Nebraska, 1997, 168-69.

No mention of the retrospective exists in the sparse documentation of Seurat's life that has come to light, but his extended series on the theme strongly suggests that he saw the Stonebreakers there. He may also have seen it earlier, in 1876, when it was on display for almost a month on rue Rochechouart in the $9^{\text {th }}$ arrondissement, just around the corner from the Seurat family home on boulevard Magenta (Exposition des 'Casseurs de Pierres', 70, rue Rochechouart, 20 April-15 May 1876).

${ }^{46}$ On Castagnary's promotion of civic naturalism, see Le Triomphe des mairies, exh. cat., Paris, 1986; and Quand Paris dansait avec Marianne, exh. cat., Paris, 1989. ${ }^{47}$ Zimmermann, Les Mondes de Seurat, 94, identifies the central figure as a ragpicker (he also suggests that the woman might be this man's wife). Georges Seurat, 1859-1891, 27, identifies the figure as a postman.

${ }^{48}$ See The Realist Tradition, exh. cat., Cleveland, 1980, 1-20.

${ }^{49}$ On the impact of Courbet's participation in the Commune both on his own subsequent artistic activity and on his reputation, see Courbet et la Commune, Paris, 2000. For a general discussion of Courbet's reputation in the 1880s, see Sanchez, Jean-Pierre, “La Critique de Courbet et la critique du réalisme entre 1880 et 1890,” Histoire et Critique des Arts 4-5 (1977-78): 76-82.

${ }^{50}$ At the Exposition Universelle of 1878 Courbet, who had just died, was represented by just one painting, The Wave (1869), then in the collection of the Musée du Luxembourg. Émile Zola, although himself often rather hostile to Courbet's work, decried his almost-total exclusion and attributed it to his participation in the Commune ('L’école française de peinture à l'exposition de 1878', in Émile Zola, Oeuvres Complètes, ed. Henri Mitterand, Paris, 2002-2010, 21 vols, 8:729-30). ${ }^{51}$ Linda Nochlin, 'The de-politicization of Gustave Courbet: Transformation and rehabilitation under the Third Republic', October 22, Autumn 1982, 64-78. 
52 On the lack of empathy in Seurat's stonebreakers and related images, see Herbert, Seurat and the Making of La Grande Jatte, 37.

${ }^{53}$ For similar observations, see Erich Franz and Bernd Growe, Georges Seurat: Drawings, trans. John William Gabriel, Boston, 1984, 57.

${ }^{54}$ Other artists who would later be key figures in neo-impressionism - most notably Signac - exhibited a similarly ambivalent response to naturalism as a radical forebear in the early 1880s. See Wright, 'Mourning, painting, and the Commune,' 239-40. ${ }^{55}$ Art historical writing now generally makes a terminological distinction between realism, impressionism, and naturalism. In the 1860s and 1870s the distinction was not held to be so clear. Zola used the term naturalism to refer to artists ranging from the Barbizon School to Manet and from the impressionists to academic or salon naturalists such as Bastien-Lepage.

${ }^{56}$ Émile Zola, 'M. Manet’, L'Evénement, 7 May 1866; in Oeuvres Complètes, 2:640: 'Tout son être le porte à voir par taches, par morceaux simples et énergiques'. Seurat could have picked up the tache from any number of naturalist precedents - from Manet but also from academic naturalists such as Bastien-Lepage or, of course, from impressionism. But it would not be surprising if he were interested in Manet who, like Courbet, was being promoted by Proust and others in the early 1880s (Michael R. Orwicz, 'Reinventing Edouard Manet: Rewriting the Face of National Art in the Early Third Republic,' in Art Criticism and its Institutions in Nineteenth-Century France, ed. Michael R. Orwicz, Manchester and New York, 1994, 125.). Seurat perhaps had Manet in mind when he designed the indeterminate suburban setting of Stonebreaker, Le Raincy: the drawing in effect twins Courbet and Manet, an alliance that would have seemed menacingly unsurprising to those conservative critics (and they were many) who lumped the two painters together (see Orwicz, 'Reinventing Edouard Manet,' 127-28).

${ }^{57}$ For an extended account of the Third Republic's promotion of naturalism as an official style, see Richard Thomson, Art of the Actual: Naturalism and Style in Early Third Republic France, New Haven, 2012.

${ }^{58}$ Zola, 'Le moment artistique', L'Evénement, 4 May 1866; in Oeuvres Complètes, 2:636: 'nos fils . . . s'extasieront en face de ses toiles.' 
59 Zola, 'Lettres de Paris. Nouvelles littéraires et artistiques', Vestnik Europy (The Herald of Europe), July 1879; in Jean-Pierre Leduc-Adine, ed., Émile Zola: Écrits sur l'art, Paris, 1991, 399, 401-02.

${ }^{60}$ Zola, 'Lettres de Paris’; in Leduc-Adine, ed., Émile Zola: Écrits sur l'art, 400: 'Si le côté technique chez lui égalait la justesse des perceptions, il serait le grand peintre de la seconde moitié du XIXe siècle.’

${ }^{61}$ Zola, 'Lettres de Paris’; in Leduc-Adine, ed., Émile Zola: Écrits sur l'art, 400: 'imparfaits et inégales . . . écolier.'

62 Zola, 'Lettres de Paris’; in Leduc-Adine, ed., Émile Zola: Écrits sur l'art, 400, 405: 'pèchent par l'insuffisance technique. . . . on peut craindre qu'ils ne fassent qu'indiquer le chemin au grand artiste de l'avenir que le monde attend'; 'La place est balayé pour un peintre de génie.'

${ }^{63}$ In 1880 Zola wrote of the impressionists: 'These are all precursors, the man of genius is not yet born' (Zola, 'Le naturalisme au Salon', Le Voltaire, 18 to 22 June 1880; in Oeuvres Complètes, 9:550: ‘Ce sont tous des précurseurs, l’homme de génie n'est pas né'). In 1881, noting that the great masters of the first naturalist generation were dead (and perhaps foretelling Manet's imminent demise), he complained that 'Today, only pupils remain. ... It only remains to wait for a painter of genius whose fist will be strong enough to impose reality’ (Zola, ‘Après une promenade au Salon’, Le Figaro, 23 May 1881; in Oeuvres Complètes, 10:845, 848: ‘Aujourd’hui, les élèves seuls demeurent. . . . Il ne reste plus à attendre qu'un peintre de génie, dont la poigne soit assez forte pour imposer la réalité’). In 1884 Zola reiterated his view of Manet as a precursor for a future master in the preface for the artist's posthumous retrospective; for discussion, see Jean-Paul Bouillon, 'Manet 1884: Un bilan critique,' in La critique d'art en France, 1850-1900: actes du colloque de Clermont-Ferrand, 25, 26 and 27 May 1987, Saint-Etienne, 1989, 159-75. In 1896 he would still be waiting for the genius to arrive, though now without any real hope: 'one has to say it, no great new painter has revealed himself, no Ingres, no Delacroix, no Courbet’ (Zola, 'Peinture', Le Figaro, 2 May 1896; in Ehrard, ed., Mon Salon, 376: 'il faut bien le dire, aucun grand peintre nouveau ne s’est révélé, ni un Ingres, ni un Delacroix, ni un Courbet'). Note that the late Manet does not figure alongside these great precedents: not even his death had persuaded Zola to promote him to their exalted company. 
${ }^{64}$ Émile Zola, 'Causerie’, La Tribune, 30 Aug. 1868; in Oeuvres Complètes, 3:67071. Zola suggested playfully that the Venus could be converted into a figure of Peace, complete with sword and wooden leg - which is to say not really Peace but a pirate, as was appropriate, he noted ironically, for the Emperor who had launched the illfated Mexican expedition of 1862-67.

65 Zola, 'Causerie’; in Oeuvres Complètes, 3:672: 'parle bien haut de son amour pour les arts. La vérité est que le second Empire ne comptera ni un grand peintre, ni un grand sculpteur, ni un grand écrivain. Les seuls artistes que l'on encourage réellement, ce sont les maçons de $\mathrm{M}$. Haussmann. On leur a livré un ville entière, et ils en ont fait une ville de plâtre, de carton-pierre et de simili-marbre.’

${ }^{66}$ Zola, ‘Causerie’; in Oeuvres Complètes, 3:672: L’âge démocratique où nous entrons exigera un art viril'.

Napoleon III’s administration attempted to repress these precursors, as Zola knew very well. Hence his labeling of art critics as ‘sergents de ville’ (Zola, Éd. Manet; in Oeuvres Complètes, 2:660), an appellation whose political subtext has gone unremarked. In 1854 Napoleon III had reformed the municipal police, tasking the newly-created sergents de ville with keeping an eye on the capital's population. So close was the association of the Emperor with the sergents de ville that he was himself represented as one in caricatures that show him cudgeling political demonstrators. Manet's equation of art critics with the sergents de ville, then, makes clear that he saw the opposition of the imperial administration to the naturalists in specifically political terms.

${ }^{67}$ Zola, 'M. Manet’; in Oeuvres Complètes, 2:638: ‘une main puissante’.

${ }^{68}$ Émile Zola, Le Sémaphore de Marseille, 27 May 1871; rpt. in Henri Mitterrand, ed., Zola journaliste, Paris, 1962, 147: 'J'ai réussi à faire une promenade dans Paris. C'est atroce. . . . Je veux simplement vous parler des tas de cadavres qu'on a empilés sur les ponts. Non, jamais, je n'oublierai l'affreux serrement de coeur que j'ai éprouvé en face de cet amas de chair humaine sanglant, jeté au hasard sur les chemins de halage. ... Ô le lugubre charnier'.

${ }^{69}$ Zola, 'Lettres de Paris’; in Leduc-Adine, ed., Émile Zola: Écrits sur l'art, 397-98.

${ }^{70}$ Zola, 'La République et la littérature', Vestnik Europy (The Herald of Europe), April 1879; in Oeuvres Complètes, 9:495, 498-99. The article was republished in the 
literary supplement of Le Figaro, 20 April 1879, and in La Revue Bleue, 25 April 1879.

${ }^{71}$ Zola, 'Le naturalisme au Salon'; in Oeuvres Complètes, 9:547.

72 'The Impressionists and Edouard Manet,' The Art Monthly Review and

Photographic Portfolio, London, 30 Sept. 1876; rpt. in Art in Theory, 1815-1900: An

Anthology of Changing Ideas, eds Charles Harrison, Paul Wood, Jason Gaiger,

Oxford, 1998, 591-92. Mallarmé presented Manet as a sharp turn away from the

Romantics of the preceding generation, 'noble visionaries of other times ... recluses

to whom were given the genius of a dominion over an ignorant multitude’

('Impressionists and Edouard Manet,' 592). Against this exclusive and elitist art,

Manet and the impressionists offered a clear sighted account of nature, an argument

Mallarmé couched in rather poetic terms: 'At that critical hour for the human race

when Nature desires to work for herself, she requires certain lovers of hers - new and

impersonal men placed directly in communion with the sentiment of their time - to

loose the restraint of education, to let hand and eye do what they will, and thus through them, reveal herself. For the mere pleasure of doing so? Certainly not, but to express herself, calm, naked, habitual, to those newcomers of to-morrow [sic], of which each one will consent to be an unknown unit in the almighty numbers of a universal suffrage, and to place in their power a newer and more succinct means of observing her. Such, to those who can see in this the representative art of a period which cannot isolate itself from the equally characteristic politics and industry, must seem the meaning of the manner of painting which we have discussed here' ('Impressionists and Edouard Manet,' 592).

${ }^{73}$ A close friend of Proust's, Manet would be pleased the following year to see the leftward turn of the republic under Gambetta, but less pleased at Castagnary's promotion of Courbet: he had long been suspicious about what he saw as the tendentious nature of Courbet's work, which was, he believed, too crudely partisan to present a truthful picture of the world. See Émile Zola, Mes haines: causeries littéraires et artistiques, Paris, 1866.

74 Émile Zola, Éd. Manet: étude biographique et critique, Paris, 1867; in Oeuvres Complètes, 2:666: 'Une tête posée contre un mur, n’est plus qu'une tache plus ou moins blanche sur un fond plus ou moins gris.' 
75 Zola, Éd. Manet; in Oeuvres Complètes, 2:666-67: 'l’observation exacte de la loi des valeurs ... un ensemble de taches justes et délicates qui, à quelques pas, donne au tableau un relief saisissant.'

${ }^{76}$ Zola, Éd. Manet; in Oeuvres Complètes, 2:667: 'Toute la personnalité de l’artiste consiste dans la manière dont son oeil est organisé: il voit blond, et il voit par masses'.

${ }^{77}$ For a recent discussion of the inherent formalism of Zola’s argument, see Carol Armstrong, Manet Manette, New Haven, 2002, 31-47.

${ }^{78}$ Zola, Éd. Manet; in Oeuvres Complètes, 2:667: 'est seulement guidé dans son choix par le désir d'obtenir de belles taches, de belles oppositions.'

${ }^{79}$ Zola, Éd. Manet; in Oeuvres Complètes, 2:673-74: 'le peintre a procédé comme la nature procède elle-même, par masses claires, par larges pans de lumière’. ${ }^{80}$ Zola, Éd. Manet; in Oeuvres Complètes, 2:674: 'Il vous fallait une femme nue, et vous avez choisi Olympia, la première venue; il vous fallait des taches claires et lumineuses, et vous avez mis un bouquet; il vous fallait des taches noires, et vous avez placé dans un coin une négresse et un chat. Qu'est-ce que tout cela veut dire? vous ne le savez guère, ni moi non plus. Mais je sais, moi, que vous avez admirablement réussi à faire une oeuvre de peintre, de grand peintre, je veux dire à traduire énergiquement et dans un langage particulier les vérités de la lumière et de l'ombre, les réalités des objets et des creatures.'

${ }^{81}$ Zola, Éd. Manet; in Oeuvres Complètes, 2:667.

${ }^{82}$ For perceptive remarks on this detail, see Bridget Alsdorf, 'Manet's quarrel with impressionism,' in Cézanne and the Modern: Masterpieces of European Art from the Pearlman Collection, exh. cat., Princeton, 2014, 88, 90. That similar marks interrupt the reflection in the mirror in The Bar at the Folies Bergères (1882) indicates the persistence with which Manet investigated paint's ability both to enact and to refuse mimesis. In The Bar the taches that mar the mirror image call into question the model of painting as reflection or window. In Young Woman with a Round Hat it is painting's relation to vision itself that is interrogated.

${ }^{83}$ For a useful account of the tache as 'double agent', both enabling mimesis and undoing it, see Maloon, ‘Towards Abstraction', 22. On the history of the 'tache' as 
critical term, see Arden Reed, Manet, Flaubert, and the Emergence of Modernism, Cambridge, 2003, 56-66.

${ }^{84}$ On the silence of Seurat's drawings, see Hauptman et al, Georges Seurat: The Drawings, 14.

${ }^{85}$ Hubert Damisch, 'Polka dots and moonbeams', in Hauptman et al, Georges Seurat, 120-21.

${ }^{86}$ The task of forgetting was brought closer to completion when the street was subsequently renamed Avenue Paul Déroulède (after a notoriously nationalist politician who as a young soldier had fought against the Commune). The avenue would later be renamed again, this time after Général Lemonnier, beheaded by the Japanese in 1945 and celebrated in France for his heroic resistance to enemy demands. 